\title{
PENERIMAAN FINANCIAL TECHNOLOGY BERBASIS TECHNOLOGY ACCEPTANCE MODEL (TAM)
}

\author{
Sutrisno, Diva Fahlevi, Sarbullah \\ STIE SEMARANG \\ nasasutrisno@yahoo.com
}

\begin{abstract}
Tecnology Acceptance Model (TAM) developed by Davis which is a successful and acceptable model in order to predict the acceptance of a new technology. In the last two years, in Indonesia there has emerged a financial technology service that was designed with the open platform principle, OVO. OVO is a service engaged in the field of financial technology, is a smart application designed to make payment services and transactions online, and has penetrated into all business expansion. The purpose of this research is to find out. the effect of perceived ease, perceived risk and attitude of use on the intention of OVO financial technology behavior in Surakarta City.

The population used in this study were all users who intended to use OVO financial technology behavior in Surakarta City amounted to 140. The sample used in this study were 60 people. Data analysis methods used are descriptive statistical analysis, validity test, Classic Assumption Test, multiple regression analysis, $t$-test statistics and the model feasibility test and the coefficient of determination.

The results of this study indicate that perceptions of ease have a positive and significant influence on the behavioral intention of OVO financial technology in the city of Surakarta with a significance of 0,000 $<0.05$. perceived risk has a positive and significant effect on the intention of OVO financial technology behavior in Surakarta City with a significance of $0.002<0.05$. usage attitude has a positive and significant influence on the intention of OVO financial technology behavior in Surakarta City with a significance of 0,000<0.05. This means that all variables affect the intention of OVO financial technology behavior in Surakarta City.

Seeing the results of the research conclusions, that Behavioral Intetion of the users stated that those interested in using OVO financial technology applications with the advantages offered such as free transfers.
\end{abstract}

Keywords: Perceived Ease of Use, Perceived Risk Attitude using Dan Behavioral Intetion 


\begin{abstract}
ABSTRAK
Tecnology Acceptance Model (TAM) yang dikembangkan oleh Davis yang merupakan suatu model yang berhasil dan dapat diterima guna untuk memprediksi penerimaan adanya suatu teknologi yang baru. Dalam dua tahun terakhir ini, di Indonesia muncul adanya layanan financial technology yang di rancang dengan prinsip open platfrom yaitu OVO. OVO adalah layanan yang bergerak dalam bidang financial technology, merupakan sebuah aplikasi smart yang dirancang guna melakukan layanan pembayaran dan transaksi secara online, dan telah merambah ke semua ekspansi bisnis. Tujuan dalam penelitian ini adalah, untuk mengetahui. pengaruh persepsi kemudahan, risiko yang dirasakan dan sikap penggunaan terhadap niat perilaku teknologi keuangan OVO di Kota Surakarta.

Populasi yang digunakan dalam penelitian ini adalah seluruh pengguna yang niat menggunakan perilaku teknologi keuangan OVO di Kota Surakarta berjumlah 140. Sampel yang digunakan dalam penelitian ini sebanyak 60 orang. Metode analisis data yang digunakan adalah analisis statistik deskriptif, Uji validitas, Uji Asumsi Klasik, analisis regresi berganda, uji statistik t dan uji kelayakan model dan koefisien determinasi.

Hasil penelitian ini menunjukkan bahwa persepsi kemudahan mempunyai pengaruh Positif dan signifikan terhadap niat perilaku teknologi keuangan OVO di Kota Surakartadengan signifikansi $0,000<0.05$. risiko yang dirasakan mempunyai pengaruh positif dan signifikan terhadap niat perilaku teknologi keuangan OVO di Kota Surakarta dengan signifikansi 0,002< 0,05. sikap penggunaan mempunyai pengaruh positif dan signifikan terhadap niat perilaku teknologi keuangan OVO di Kota Surakarta dengan signifikansi 0,000 $<0.05$. Hal ini berarti bahwa semua variabel berpengaruh terhadap niat perilaku teknologi keuangan OVO di Kota Surakarta.

Melihat hasil kesimpulan penelitian, bahwa Behavioral Intetionpara pengguna menyatakan bahwa para berminat menggunakan aplikasi teknologi keuangan OVO dengan kelebihan yang ditawarkan seperti gratis transfer.
\end{abstract}

\title{
Kata kunci : Persepsi Kemudahan Penggunaan, Persepsi Sikap Risiko menggunakan Dan Niat Prilaku.
}




\section{PENDAHULUAN}

Perubahan teknologi dalam dekade terakhir ini, berkembang dengan sangat pesat. Hal ini secara signifikan mempengaruhi cara dan gaya hidup seseorang. Komputer, handphone, internet, jaringan sosial, dan media sosial sekarang telah menjadi perangkat yang sangat diperlukan bahkan menjadi kebutuhan yang wajib bagi semua lapisan masyarakat luas (Jantarakolica, 2018).

Salah satu faktor pendorongnya adalah adanya kemudahan dalam mengakses dan mendapatkan informasi yang diperoleh melalui internet sehingga masyarakat dapat untuk terus mengikuti perkembangannya. Seiring perkembangan tersebut, kini internet juga merambah ke dunia financial technology dimana seseorang dimanjakan dengan adanya teknologi digital yang kian mempermudah seseorang untuk bertransaksi tanpa harus mengeluarkan uang cash.

Financial technology atau sering disebut fintech merupakan suatu inovasi baru dibidang finansial (keuangan) yang bertujuan untuk mempermudah pengguna dalam melakukan kegiatan finansial dan memudahkan perusahaan dalam memberikan pelayanan keuangannya (Huwaydi et al 2018).

Dalam penggunanaan dan penerimaan teknologi baru, tidak semua teknologi mudah diterima oleh masyarakat, karena dalam penerimaannya tetap membutuhkan proses dan waktu yang cukup untuk menyesuaiakannya (Juhri dan Dewi, 2017).

Hal inilah yang kemudian menjadi bahan peneliti yang terkait dengan kepercayaan masyarakat dalam mengadopsi teknologi baru dengan menggunakan Technology Accepteance Model (TAM) (Davis, 1989; Davis 1993; Davis 1996; Davis et al 1989; Venkatesh dan Davis; 2000 dalam Schwarz et al 2004).

\section{MASALAH PENELITIAN}

Berdasarkan latar belakang di atas, maka peneliti akan melakukan penelitian terhadap teknologi baru di Kota Surakarta yaitu OVO yang merupakan salah satu dari bentuk financial technology.

\section{KAJIAN TEORITIS}

1. Technology Acceptance Model (TAM) Technology Accepteance Model (TAM) diperkenalkan pertama kali oleh Davis pada tahun 1986, yang merupakan adopsi dari Theory of Reasoned Action (TRA) yang dibuat khusus untuk pemodelan penerimaan suatu teknologi baru. Tecnology Acceptance Model (TAM) yang dikembangkan oleh Davis (1989).

Modifikasi model TAM dilakukan oleh Venkantesh (2002) dengan menambahkan variable trustdengan judul: $\underline{\text { Trust enhanced }}$ Technology 
Acceptance Model, yang meneliti tentang hubungan antar variabel TAM dan trust. $\quad$ Modifikasi TAM lain yaitu Trust and Risk in Technology Acceptance Model (TRITAM) yang menggunakan variabel kepercayaan dan resiko bersama variabel TAM (Lui and Jamieson, 2003).

Pengguna yang potensial percaya bahwa aplikasi tertentu berguna, mungkin mereka, pada saat yang sama, percaya bahwa sistem ini terlalu sulit untuk digunakan dan manfaat yang di dapat dari penggunaan yang melebihi upaya menggunakan aplikasi. Artinya, di samping manfaat atau kegunaannya, penerapan sistem teknologi informasi akan dipengaruhi juga oleh kemudahan yang dirasa penggunaan (perceived ease of use). Oleh sebab itu Davis menambahkan dua komponen itu pada model TAM.

2. Persepsi Kemudahan Penggunaan (Perceived Ease of Use)

Menurut Nurrahmanto (2015) Persepsi kemudahan penggunaan menunjukkan tingkat dimana seseorang meyakini bahwa penggunaan sistem informasi yang dalam hal ini adalah minat menggunakan (OVO Cash) adalah mudah dan tidak memerlukan usaha yang keras dari pemakainya untuk dapat menggunakannya.
OVO adalah sebuah aplikasi smart yang memberikan layanan pembayaran dan transaksi secara online (OVO Cash). Seseorang juga bisa berkesempatan untuk mengumpulkan poin setiap kali melakukan transaksi pembayaran melalui OVO. Sehingga teknologi ini mudah digunakan karena dalam transaksi nasabahnya tanpa mengharuskan membawa cash terlalu banyak. Salah satunya cukup dengan menunjukkan aplikasi OVO yang didalamnya terdapat saldo cash maupun point. Berbagai kemudahan yang didapatkan oleh pengguna OVO tersebut dapat dikategorikan sebagai Perceived Ease of Use menurut teori Technology Acceptance Model.

Menurut Sebayang (2017) kemudahan penggunaan merupakan suatu keyakinan tentang proses pengambilan keputusan. Jika seseorang merasa yakin bahwa sistem informasi mudah digunakan maka dia akan menggunakannya. Sebaliknya,jika seseorang merasa yakin bahwa sistem informasi tidak mudah digunakan maka dia tidak akan menggunakannya.

3. Pengertian Risiko Persepsi (Perceived Risk)

Menurut Ferrinadewi (2008) Risiko Persepsi (Perceived Risk) adalah cara pandang tentang suatu hal, persepsi merupakan proses yang kompleks, 
seringkali terjadi dimana pesan yang satu tidak berhubungan dengan pesan yang lainnya dan akhirnya memasuki otak konsumen karena itu memahami proses persepsi sangat penting bagi produsen atau pembisnis agar dapat, menciptakan komunikasi yang efektif dengan konsumen.

Menurut Suryani (2008) risiko yang dipersepsikan (perceived risk) dapat adalah sebagai ketidakpastian yang dihadapi konsumen ketika mereka tidak mampu melihat kemungkinan yang akan terjadi dari keputusan pembelian yang dilakukan. Berkaitan dengan adanya persepsi konsumen terdapat persepsi terhadap risiko atau perceived risk, persepsi terhadap kualitas atau perceived quality, persepsi terhadap pengorbanan atau perceived sacrifice, persepsi terhadap nilai atau perceived value.

Risiko cenderung berdampak negatf bagi penggunanya. Dijelaskan oleh Lee (2009) dalam Wang et al (2018) bahwa risiko yang terkait dengan penggunaannya merupakan masalah yang seringkali konsumen khawatirkan, dan risiko dianggap sebagai faktor yang penting dalam pengadopsian suatu teknologi baru, mengingat bahwa layanan mobile begitu cepat dalam berinovasi.
4. Pengertian Sikap Penggunaan Teknologi (Attitude usingToward Technology)

Menurut Sumarwan (2011). sikap penggunaan merupakan ungkapan perasaan positif-negativ atau sukatidak suka terhadap suatu obyek atau perilaku. Sikap penggunaan (attitude toward using) dalam TAM dikonsepkan sebagai sikap terhadap penggunaan sistem yang berbentuk penerimaan atau penolakan sebagai dampak bila seseorang menggunakan suatu teknologi dalam pekerjaannya.

Menurut usuma dan Susilowati (2007) Attitude toward using diukur dengan indikator teknologi dinilai perlu, menghimbau semua bank menggunakan internet, serta menggunakan internet banking merupakan ide yang bijaksana. Sikap merupakan evaluasi positif atau negatif dalam melakukan perilaku.

Chauhan, (2015) menjelaskan bahwa attitude toward technology merupakan unsur yang utama yang mempengaruhi niat seseorang untuk menggunakan teknologi tersebut. Menurut Orientario et al (2017) attitude toward technology didefnisikan sebagai perasaan batin individu yang menunjukkan apakah dia suka atau tidak suka sesuatu seperti layanan ataupun merk. Sikap penggunaan tersebut juga akan mendorong kecenderungan untuk 
bertindak dengan niat yang baik atau buruk.

5. Pengertian Niat Perilaku (Behavioral Intention)

Menurut Chauhan (2015) Behavioural Intention to Use sebagai tingkat seberapa kuat keinginan atau dorongan seseorang untuk melakukan perilaku tertentu. Adanya kemudahan yang diberikan suatu layanan, maka akan meningkatkan niat pengguna untuk tetap menggunakannya.

Oentario et al (2017). Dibuktikan dengan adanya informasi dari kontan.co.id bahwa sepanjang tahun 2018 pengguna OVO meningkat 400\% dalam setahun, sementara volume transaksi OVO tumbuh 75 kali lipat di tahun lalu, atau sekitar satu miliyar transaksi dan selama ini OVO telah menggaet 32.000 merchant dalam layanannya. Hal tersebut menunjukkan bahwa sikap atau minat seseorang ke OVO cukup tinggi.

Menurut Jogiyanto (2007) niat (intention) adalah keinginan untuk melakukan perilaku, niat merupakan komponen dalam diri individu yang mangacu pada keinginan untuk melakukan suatu perilaku, sedangkan perilaku adalah tindakan nyata dari keinginan berperilaku tersebut, niat erat kaitannya dengan dorongan yang timbul pada diri seseorang secara sadar atau tidak sadar untuk melakukan sesuatu tindakan dengan tujuan tertentu.

Menurut Menurut Sulistiani (2012) niat tidak selalu statis dan dapat berubah seiring berjalannya waktu, dapat disimpulkan semakin panjang interval waktu maka semakin besar kemungkinan niat seseorang dapat berubah.

Dari penjelasan di atas dapat disimpulkan bahwa behavioral intention merupakan niat seseorang yang mendorong untuk menerima atau menolak adanya suatu produk atau layanan baru. Dalam penelitian Juhri dan Dewi (2017) mengkonsepkan bahwa Behavioural Intention dapat diukur melalui indikator diantaranya: Willingness to Use, Favorable Opinion, Intention to Use.

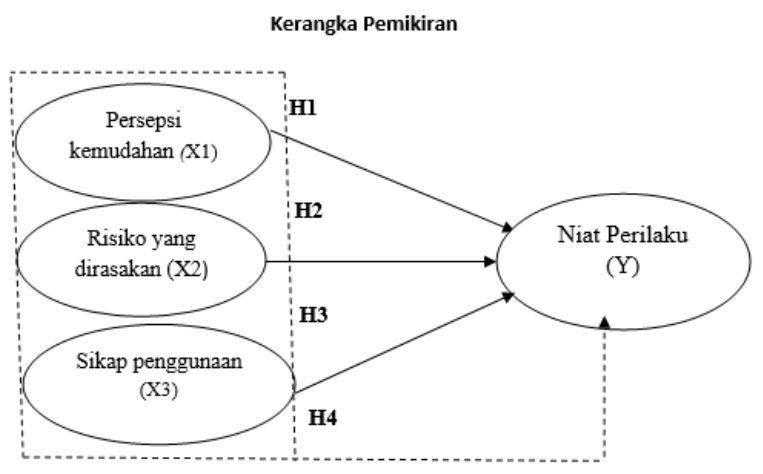

\section{METODOLOGI}

Populasi merupakan gabungan seluruh elemen yang memiliki serangkaian karakteristik serupa untuk kepentingan riset (Malhotra, 2005) serta sekumpulan unsur 
atau elemen yang menjadi obyek penelitian, dapat berupa lembaga, individu, kelompok, dokumen, atau konsep.

Populasi yang digunakan dalam penelitian ini adalah seluruh pengguna yang niat menggunakan perilaku teknologi keuangan OVO di Kota Surakarta berjumlah 140.

Adapun karakteristik yang digunakan dalam pengambilan sampel adalah. Sampel dalam penelitian ini adalah niat perilaku teknologi keuangan OVO di Kota Surakarta. Teknik yang digunakan dalam pengambilan sampel dalam penelitian ini adalah metode purposive samplingDengan demikian jumlah sampel yang harus diambil dalam penelitian ini adalah sebesar 60 orang atau yang niat menggunakan perilaku teknologi keuangan OVO di Kota Surakarta.

Variabel penelitian menurut Sugiyono (2007) adalah segala sesuatu hal yang berbentuk apa saja yang ditetapkan oleh peneliti untuk dipelajari sehingga diperoleh informasi tentang hal tersebut, dan kemudian ditarik kesimpulannya. Variabel bebas (independen) dalam penelitian ini adalah modal yangdiukur dalam penelitian ini adalah:

1. Persepsi Kemudahan $\left(\mathrm{X}_{1}\right)$ Persepsi Kemudahan (Peceived ease of use) adalah suatu kemudahan yang diberikan oleh suatu layanan teknologi tanpa harus mengeluarkan usaha atau bebas.
2. Risiko yang dirasakan $\left(\mathrm{X}_{2}\right)$, Risiko yang dirasakan (Perceived risk) adalah dampak yang ditimbulkan oleh suatu teknologi yang akan diadopsi, sehingga pengguna harus memikirkannya terlebih dahulu ketika akan menggunakannya

3. Sikap Penggunaan $\left(X_{3}\right)$, Sikap Penggunaan (Attitude toward technology) merupakan sikap dari diri seseorang tentang adanya suatu teknologi baru, yang menunjukkan apakah teknologi tersebut dapat diterima atau tidak.

Menurut Sugiyono (2007). Variabel Dependen merupakan variabel yang dipengaruhi akibat karena adanya variabel bebas. Variabel terikat dalam penelitian ini adalah Niat Perilaku Teknologi Keuangan OVO Niat Perilaku Teknologi Keuangan OVO (Behavioral intention) merupakan niat seseorang yang mendorong untuk menerima atau menolak adanya suatu produk atau layanan baru.

Metode analisa data dalam penelitian ini adalah: Uji Asumsi Klasik. Tujuan pengujian asumsi klasik ini adalah untuk menguji dan mengetahui kelayakan atas model regresi yangdigunakan dalam penelelitian ini, pengujian meliputi: Uji Normalitas, Uji Multikolinieritas, Uji Heteroskedastisitas.Uji Signifikansi Parameter Individual (Uji Statistik t), Uji signifikansi Simultan (Uji statistik F), 
Koefisien Determinasi (R2), Analisis regresi linier berganda

$$
\mathrm{Y}=\text { Niat Perilaku Teknologi Keuangan }
$$
OVO

$\beta_{0}+\beta_{1}$ Persepsi Kemudahan $+\beta_{2}$ Risiko yang dirasakan $+\beta 3$ Sikap Penggunaan $+\varepsilon$

$\mathrm{X}_{1} \quad=$ Persepsi Kemudahan

$\mathrm{X}_{2} \quad$ = Risiko yang dirasakan

$\mathrm{X}_{3} \quad=$ Sikap Penggunaan

$\varepsilon \quad=$ kesalahan residual (eror)

\section{PEMBAHASAN}

Berikut ini akan dijelaskan mengenai karakteristik responden berdasarkan, jenis kelamin, dan penghasilan. Tabel berikut adalah tabulasi responden berdasarkan jenis kelamin.

Tabel 1

Responden Berdasarkan Jenis Kelamin

\begin{tabular}{|l|c|c|}
\hline \multicolumn{1}{|c|}{$\begin{array}{c}\text { Jenis } \\
\text { Kelamin }\end{array}$} & Jumlah & $\begin{array}{c}\text { Prosentase } \\
(\%)\end{array}$ \\
\hline Perempuan & 13 & $30 \%$ \\
\hline Laki-Laki & 47 & $70 \%$ \\
\hline Jumlah & 60 & $100 \%$ \\
\hline
\end{tabular}

Berdasarkan pada tabel diatas dapat diketahui bahwa sebagian besar responden pada penelitian ini adalah responden lakilaki yaitu 47 orang atau $70 \%$ dan reponden perempuan sebanyak 13 orang atau $30 \%$.
Tabel 2

Responden Berdasarkan Penghasilan

\begin{tabular}{|l|c|c|}
\hline $\begin{array}{c}\text { Penghasilan } \\
\text { /(Bulan) }\end{array}$ & Jumlah & $\begin{array}{c}\text { Prosentase } \\
(\%)\end{array}$ \\
\hline$<3$ juta & 32 & $56 \%$ \\
\hline $3-5$ juta & 9 & $17 \%$ \\
\hline$>5$ juta & 19 & $27 \%$ \\
\hline Jumlah & 60 & $100 \%$ \\
\hline
\end{tabular}

Berdasarkan pada tabel diatas dapat diketahui bahwa sebagian besar responden pada penelitian ini adalah responden berpenghasilan kurang dari 3 juta per bulan sebanyak 42 orang $56 \%$ dan sebanyak 19 orang yang berpenghasilan 3-5 juta per bulan sebanyak $17 \%$ dan 29 orang berpengahasilan lebih dari 5 juta per bulan sebanyak $27 \%$.

\section{Pengujian Asumsi Klasik}

Analisis uji asumsi klasik untuk menguji kelayakan data yang digunakan dalam penelitian (Imam Ghozali, 2005 : 19)

a. Uji Normalitas

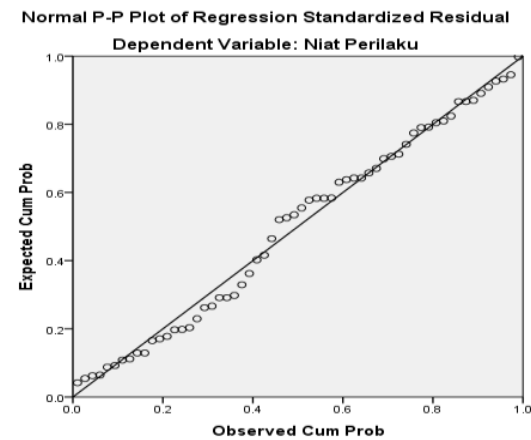

Dari gambar diatas menunjukkan bahwa plotting data tidak jauh dari garis diagonalnya dan menempel pada garis diagonal.Hal ini berarti bahwa data terdistribusi normal. 
b. Uji Multikoleniaritas

Uji multikolonieritas bertujuan untuk menguji apakah dalam model regresi ditemukan adanya korelasi antar variabel bebas.

Tabel 3

Uji Multikoleniaritas

\begin{tabular}{|c|c|c|c|}
\hline \multirow{3}{*}{ Model } & & \multirow{2}{*}{\multicolumn{2}{|c|}{ Collinearity Statistics }} \\
\hline & & & \\
\hline & & Tolerance & VIF \\
\hline \multirow{4}{*}{1} & (Constant) & & \\
\hline & Persepsi Kemudahan & .723 & 1.382 \\
\hline & Risiko yang dirasakan & .730 & 1.371 \\
\hline & Sikap Penggunaan & .640 & 1.563 \\
\hline
\end{tabular}

Dari tabel tersebut terlihat setiap variabel bebas mempunyai nilai tolerance $\geq 0,1$ dan nilai $\mathrm{VIF} \leq 10$. Jadi dapat disimpulkan bahwa tidak ada multikolinieritas antar variabel bebas dalam model regresi ini.

c. Uji Heteroskedastisitas

Uji Heteroskedastitas bertujuan menguji apakah dalam regresi terjadi ketidaksamaan variance dari residual suatu pengamatan ke pengamatan yang lain.

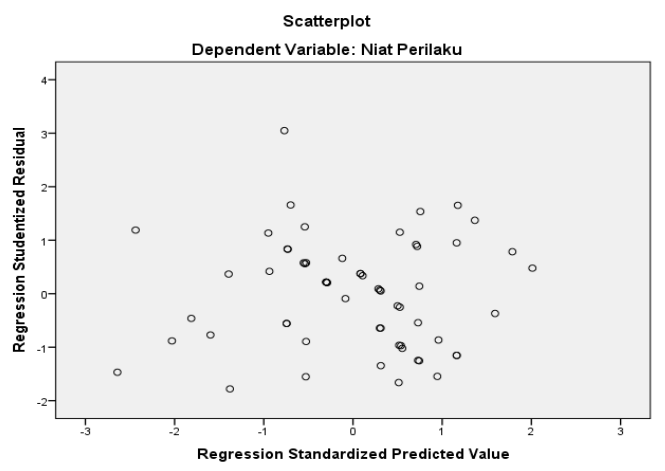

Pada gambar di atas menunjukan hasildai uji heteroskedastisitas adalah dengan mengamatipenyebaran yang acak menunjuk kan model regresi yang baik, dengan kata lain tidak terjadi heterokedastisitas.

2. Analisis regresi Linier Berganda

Analisis regresi linier berganda pada dasarnya adalah studi mengenai ketergantungan variabel dependen (terikat) dengan satu atau lebih variabel independen, hasil dari uji regresi linier berganda adlah sebagai berikut:

Tabel 4

Regresi Linier Berganda

\begin{tabular}{|c|c|c|c|}
\hline \multirow{3}{*}{ Model } & \multirow{2}{*}{\multicolumn{2}{|c|}{ Unstandardized Coefficients }} & \\
\hline & & & \multirow{2}{*}{$\begin{array}{l}\text { Standardized } \\
\text { Coefficients } \\
\text { Beta }\end{array}$} \\
\hline & B & Std. Error & \\
\hline (Constant) & .975 & 1.376 & \\
\hline 1 Persepsi Kemudahan & .411 & .103 & .359 \\
\hline Risiko yang dirasakan & .434 & .130 & 299 \\
\hline Sikap Penggunaan & .437 & .116 & .361 \\
\hline
\end{tabular}

Dari hasil analisis dengan program SPSS versi 16 tersebut, maka dapat diketahui persamaan regresi dari penelitian ini. Adapaun persamaan regresi linier yang terbentuk adalah:

$$
\begin{aligned}
\mathrm{Y}= & 0,975+0,411 \mathrm{X}_{1}+0,434 \mathrm{X}_{2}+ \\
& 0,437 \mathrm{X}_{3}+\mathrm{e} .
\end{aligned}
$$

\section{Uji Koefisien Determinasi}

Uji ini digunakan untuk mengetahui seberapa besar pengaruh variabel bebas secara bersama-sama terhadap variabel terikat. Namun kelemahan mendasar penggunaan koefisien determinasi $\left(\mathrm{R}^{2}\right)$ adalah bias terhadap jumlah variabel independen (bebas) yang dimasukkan ke dalam model. Hasildarikoefisien determinasisebagaiberikut: 
Tabel 5

Koefisien Determinasi

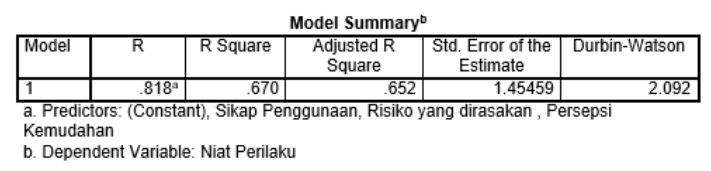

Dari tabel 5 diatas, angka koefisien determinasi ( $R$ Square) sebesar 0,670 Hal ini berarti bahwa variabel pengaruh persepsi kemudahan, risiko yang dirasakan dan sikap penggunaan terhadap niat perilaku teknologi keuangan OVO di Kota Surakarta mempunyai peranan $67,0 \%$ secara bersama-sama untuk dapat menjelaskan atau menerangkan variabel niat perilaku teknologi keuangan OVO di Kota Surakarta. Sedangkan sisanya sebesar 33,0\% (100\% - 33,0\%) dijelaskan oleh variabel lain yang mempengaruhi Niat Perilaku teknologi keuangan OVO di Kota Surakarta.

\section{Hipotesis}

a. Uji Kelayakan Model

Uji kelayakan model dimaksudkan untuk mengetahui pengaruh Variabel Independent persepsi kemudahan $\left(\mathrm{X}_{1}\right)$, risiko yang dirasakan $\left(\mathrm{X}_{2}\right)$ dan sikap penggunaan $\left(\mathrm{X}_{3}\right)$ terhadap Variabel Dependent niat perilaku teknologi keuangan OVO di Kota Surakarta (Y)

Berdasarkan tabel hasil pengujian statistik dengan menggunakan SPSS 16 didapatkan nilai $F_{\text {hitung }}=37,828$ sedangkan nilai $\mathrm{F}_{\text {tabel }}(\mathrm{a}=0,05$, df pembilang $=\mathrm{k}=4 \mathrm{df}=(\mathrm{n}-\mathrm{k}),(\mathrm{k}-1)$
$=(60-4),(4-1)=(55),(3) F_{\text {tabel }}$

$=2.70 F_{\text {hitung }}(37,828)>F_{\text {tabel }}(2.70)$

Angka signifikansi $=0,000<\mathrm{a}=0,05$

Dengan kriteria diatas maka Ho ditolak dan Ha diterima

Tabel 6

Uji Kelayakan Model

\begin{tabular}{|ll|r|r|r|r|r|}
\hline \multicolumn{7}{|c|}{ ANOdel $^{\mathrm{a}}$} \\
\hline \multirow{4}{*}{1} & Regression & Sum of Squares & \multicolumn{1}{c|}{ df } & Mean Square & F & Sig. \\
\hline & Residual & 240.113 & 3 & 80.038 & 37.828 & $.000^{\mathrm{a}}$ \\
& Total & 118.487 & 56 & 2.116 & & \\
\hline
\end{tabular}

Dari kriteria diatas dapat dinyatakan bahwa Ho ditolak dan $\mathrm{Ha}$ diterima atau dengan kata lain ada pengaruh yang signifikan antara persepsi kemudahan, risiko yang dirasakan, sikap penggunaanterhadap niat perilaku teknologi keuangan OVO di Kota Surakarta Angka signifikansi ditunjukan pada tabel 4.8 sebesar 0,000 dan nilai $F$ hitung sebesar 37,828 yang berati sangat kuat.

b. Uji Hipotesis Parsial Dengan T-test Uji t digunakan untuk mengetahui sejauh mana variabel bebas berpengaruh secara parsial terhadap variabel terikat, dengan tingkat kesalahan $5 \%$. 
Tabel 7

Hasil Uji Hipotesis Parsial

Dengan t-test

Coefficients $^{\mathrm{a}}$

\begin{tabular}{|c|c|c|}
\hline Model & $\bar{t}$ & Sig. \\
\hline (Constant) & .708 & .482 \\
\hline Persepsi Kemudahan & 3.977 & .000 \\
\hline Risiko yang dirasakan & 3.328 & .002 \\
\hline Sikap Penggunaan & 3.764 & .000 \\
\hline
\end{tabular}

a. Pengujian hipotesis 1

Variabel Persepsi Kemudahan terhadapniat perilaku teknologi keuangan OVO.Berdasarkan tabel Hasil Uji t untuk Variabel persepsi kemudahan, diperoleh nilai $t_{\text {hitung }}=$ 3,977 Sedangkan $t_{\text {tabel }}(a=0,05, d k$ $=\mathrm{n}-3, \mathrm{dk}=60-3=57)$ adalah $1,66 t_{\text {hitung }}(3,977)>t_{\text {tabel }}(1,66)$. Angka signifikansi $=0,000<\mathrm{a}=$ 0,05 (Ho ditolak dan Ha diterima). Berdasarkan kriteria diatas dapat diketahui bahwa pada taraf signifikansi 0,05 variabel persepsi kemudahan mempunyai pengaruh yang signifikan terhadap variabel niat perilaku teknologi keuangan OVO di Kota Surakarta.

b. Pengujian hipotesis 2

Variabel risiko yang dirasakan terhadap niat perilaku teknologi keuangan OVO.Berdasarkan tabel hasil Uji t untuk variabel risiko yang dirasakan, diperoleh nilai $\mathrm{t}$ hitung $=$ 3,328 sedangkan $t_{\text {tabel }}(\mathrm{a}=0,05, \mathrm{dk}$ $=\mathrm{n}-3, \mathrm{dk}=60-3=57)$ adalah $1,66 \mathrm{t}_{\text {hitung }}(3,328)>\mathrm{t}_{\text {tabel }}(1,66)$ c. Pengujian hipotesis 3

Variabel Sikap Penggunaan terhadap niat perilaku teknologi keuangan OVO. Berdasarkan tabel hasil Uji t untuk variabel Sikap penggunaan, diperoleh nilai $t_{\text {hitung }}=3,764$ sedangkan $\mathrm{t}$ tabel $(\mathrm{a}=0,05, \mathrm{dk}=\mathrm{n}-$ $3, \mathrm{dk}=60-3=57)$ adalah $1,66 \mathrm{t}_{\text {hitung }}$ $(3,764)>t_{\text {tabel }} \quad(1,66)$ Angka signifikansi $=0,000<\mathrm{a}=0,05$ ( Ho ditolak dan $\mathrm{Ha}$ diterima ). Berdasarkan kriteria diatas dapat diketahui bahwa pada taraf signifikansi 0,05 Variabel sikap penggunaan mempunyai pengaruh yang signifikan terhadap variabel niat perilaku teknologi keuangan OVO di Kota Surakarta.

Hasil penelitian menunjukan bahwa variabel Persepsi Kemudahan mempunyai pengaruh Positif dan signifikan terhadap Niat Perilaku teknologi keuangan OVO di Kota Surakarta. Hal ini ditunjukan dengan nilai koefesien regresi terbesar 0,411. Sedangkan untuk nilai $\mathrm{t}$ hitung $(3,977)>\mathrm{t}$ tabel $(1,66)$ dan sign $(0,000)<\operatorname{sign} a(0,05)$, sehingga hipotesis pertama yang diajukan ada pengaruh Positif dan signifikan variabel Persepsi Kemudahan terhadap Niat Perilaku teknologi keuangan OVO di Kota Surakarta.

Haltersebutdidukung denganpenelitianyang dilakukanolehMochamad Ilhaq Almalis (2019) yang menunjukkan bahwa Berdasarkan perhitungan dan hasil Khasiat 
yang Dirasakan dan Trust memiliki pengaruh signifikan terhadap keputusan untuk menggunakan PermataMobile SMARTCX Bank Permata. Kemudahan Penggunaan dan Biaya Persepsi diketahui memiliki pengaruh signifikan terhadap keputusan pelanggan untuk menggunakan PermataMobile SMARTCX Permata Bank di Surabaya.

Hasil penelitian ini menunjukan bahwa variabel Risiko yang dirasakan mempunyai pengaruh positif dan signifikan terhadap Niat Perilaku teknologi keuangan OVO di Kota Surakarta. Hal ini menunjukan dengan nilai koefesien regresi sebesar 0,434. Sedangkan untuk nilai $t$ hitung $(3,328)>t$ tabel $(1,66)$ dan sign $(0,002)<\operatorname{sign} a(0,05)$, sehingga hipotesis kedua yang diajukan ada pengaruh signifikan Risiko yang dirasakan terhadap Niat Perilaku teknologi keuangan OVO di Kota Surakarta, terbukti dapat diterima.

Hasil penelitian ini sesuai dengan Setyo Ferry Wibowo (2018), Temuan mengejutkan menunjukkan bahwa dampak Hasil uji deskriptif menunjukkan; yang signifikan pengaruh persepsi manfaat terhadap niat untuk menggunakan kartu the e-money, pengaruh signifikan dari persepsi kemudahan penggunaan terhadap niat untuk menggunakan uang elektronik kartu, pengaruh signifikan ketersediaan fitur terhadap niat untuk menggunakan kartu emoney dan pengaruhsignifikan kepercayaan terhadap niat untuk menggunakan e-money kartu.

Hal ini menunjukan dengan nilai koefesien regresi sebesar 0,437. Sedangkan untuk nilai $\mathrm{t}_{\text {hitung }}(3,764)>\mathrm{t}_{\text {tabel }}(1,66)$ dan sign $(0,000)$ $<$ sign $a(0,05)$, sehingga hipotesis terakhir yang diajukan ada pengaruh signifikan Sikap Penggunaan terhadap Niat Perilaku teknologi keuangan OVO di Kota Surakarta, terbukti dapat diterima.

Hal ini di perkuat dengan penelitian terdahulu milik Shang Yu Chen dan Chung Cheng Lu (2017), dengan hasil penelitian yang menemukan bahwa Bahwa perceived usefulness dan perceived of use berpengaruh positif terhadap attitude, dan attitude berpengaruh positif terhadap intention.

\section{KESIMPULAN}

1. Variabel Persepsi Kemudahan mempunyai pengaruh Positif dan signifikan terhadap Niat Perilaku teknologi keuangan OVO di Kota Surakarta. Hal ini ditunjukan dengan nilai koefesien regresi terbesar 0,411 . Sedangkan untuk nilai $\mathrm{t}$ hitung $(3,977)>\mathrm{t}$ tabel $(1,66)$ dan sign $(0,000)$ Kesimpulan kesimpulan kesimpulan kesimpulan kesimpulan kesimpulan kesimpulan kesimpulan kesimpulan kesimpulan kesimpulan kesimpulan kesimpulan.

2. Variabel Risiko yang dirasakan mempunyai pengaruh positif dan signifikan terhadap Niat Perilaku 
teknologi keuangan OVO di Kota Surakarta. Hal ini menunjukan dengan nilai koefesien regresi sebesar 0,434 . Sedangkan untuk nilai $\mathrm{t}$ hitung $(3,328)>\mathrm{t}$ tabel $(1,66)$ dan sign $(0,002)$.

3. Variabel sikap penggunaan mempunyai pengaruh positif dan signifikan terhadap niat perilaku teknologi keuangan OVO di Kota Surakarta. Hal ini menunjukan dengan nilai koefesien regresi sebesar 0,437. Sedangkan untuk nilai $\mathrm{t}$ hitung $(3,764)>t_{\text {tabel }}(1,66)$ dan sign $(0,000)$

Beberapa saran yang dapat diberikan terkait dengan hasil penelitian adalah sebagai berikut :

1. Variabel Persepsi Kemudahan, yang menyatakan bahwa aplikasi teknologi keuangan OVO mudah di download dari Play Store maupun App store lainnya. Namun, nilai terkecil adalah para pengguna merasa agak kesulitan untuk terampil dalam menggunakan aplikasi teknologi keuangan OVO. Oleh karena itu, teknologi keuangan OVO perlu memberikan tutorial yang berkaitan dengan transaksi sehari-hari terlebih dahulu misalnya transfer menggunakan send it, membeli pulsa, membayar kebutuhan utilitas dan lainlain, sehingga para pengguna bisa terampil dalam bertransaksi.

2. Variabel sikap penggunaan yang menyatakan bahwa aplikasi teknologi keuangan OVO membantu dalam kegiatan bertansaksi sehari-hari menjadi lebih mudah, Namun pengguna menyatakan bahwa aplikasi teknologi keuangan OVO belum bisa meningkatkan kinerjanya seperti membayar tagihan kartu kredit, tagihan pulsa, dll. Dalam hal ini, dapat dihubungkan ke masalah fitur sebelumnya yang mana masih ada beberapa pengguna belum tau isi dari fitur-fitur pada aplikasi teknologi keuangan OVO. Maka dari team lapangan pihak teknologi keuangan OVO lebih memperhatikan hal-hal yang berkaitan dengan transaksi sehari-hari sehingga para pengguna merasakan manfaat dari aplikasi teknologi keuangan OVO untuk meningkatkan kinerja dalam bertransaksi.

3. Variabel Risiko yang dirasakan memiliki pengaruh terhadap terhadap niat perilaku teknologi keuangan OVO di Kota Surakarta. Hal ini dikarenakan Responden terdiri dari konsumen yang pernah membeli atau memesan kebutuhannya melalui teknologi keuangan OVO, sehingga, mereka sudah terbiasa melakukan transaksi secara online dan mengerti betul tentang risiko yang memungkinkan terjadi. Sehingga peningkatan tingkat keamanan dan security yang tinggi yang disediakan penyedia layanan keuangan OVO. 
4. Variabel niat perilakupara pengguna menyatakan bahwa para berminat menggunakan aplikasi teknologi keuangan OVO dengan kelebihan yang ditawarkan seperti gratis transfer. Namun para responden masih belum memiliki keinginan untuk menggunakan aplikasi teknologi keuangan OVO sebagai rekening utama. Oleh karena itu, teknologi keuangan OVO perlu meyakinkan para pengguna dengan menonjolkan kelebihan teknologi keuangan OVO.

\section{DAFTAR PUSTAKA}

Adams, D.A., R.R. Nelson, P. A. Todd, 1992. Perceived Usefulness, Ease of Use

and Usage of Information Technology: A Replication, MIS Quarterly, 16 (2), pp. 227-247.

Ajzen, I., Fishbein, M. 1980, Understanding Attitudes and Predicting Social Behavior. Englewood Cliffs, NJ: Prentice-Hall.

Ali N, Muhammad., Junjie $\mathrm{Wu}$, Milton Yago, Haohong Li. 2000. Influence of

Psychographics and Risk Perception on Internet Banking Adoption: Current State of Affairs in Britain, International Journal of Economics and Financial Issues, 5(2), 461-468.
Al-Smadi, Mohammad O. 2011. The Impact of E-Banking on The Performance of

Jordanian Banks.Journal of Internet Banking and Commerce, 16(2), 437-446.

Al-Sukkar\&Hasan H. 2005, Toward a Model for the Acceptance of Internet Banking in Developing Countries, Information Technology for Development,Vol. 11, No. 4, pp.381398.

Amin, Hanudin. 2011. Internet Banking Adoption Among Young Intellectuals.Journal of Internet Banking and Commerce, 34(6), 437446

Black, N., J., Lockett, A., Ennew, C., Winklhofer, H., McKechnie, S., 2002,Modelling Consumer Choice of Distribution Channels: an Illustration fromFinancial Services, The International Journal of Bank Marketing,Vol. 20,pp. 161-173

Bradley L. and Stewart K. 2003.Delphi Study of Internet banking”, $M C B U P$ Limited pp. 272-281.

Bungin Burhan. 2008. MetodelogiPenelitianSosial Format-Format Kuantitatif Dan Kualitatif. Surabya, Airlangga University 